\title{
Correction: Mechanisms of stomatal development: an evolutionary view
}

Anne Vatén ${ }^{1,2}$ and Dominique C Bergmann ${ }^{1,3^{*}}$

The following corrections correspond to our recently published review article [1].

Figure 1, the note of true stomata should be placed to the left of the branchpoint for mosses and hornworts, as both groups possess stomata.

Figure 2, Fig $2 \mathrm{C}$ is Orthotrichum anomalum. Full citations for images used in this figure are:

(A) Edwards D, Kerp H, Hass H: Stomata in early land plants: an anatomical and ecophysiological approach.

J Exp Bot 1998, 49(Suppl 1):255-278, reprinted by permission of Oxford University Press.

(B-C) Ligrone R, Duckett JG, Renzaglia KS: Major transitions in the evolution of early land plants: a bryological perspective. Ann Bot 2012, 109:851-871, reprinted by permission of Oxford University Press.

(D) de León MEM, Pérez-García B, Márquez-Guzmán J, Mendoza-Ruiz A: Developmental gametophyte morphology of seven species of Thelypteris subg. Cyclosorus (Thelypteridaceae). Micron 2008, 39:1351-1362, reprinted by permission of Elsevier. (E) Kim KW, Lee S, Bae S, Kim P: 3d surface profiling and high resolution imaging for refining the florin rings and epicuticular wax crystals of Pinus koraiensis needles. Microsc Res Tech 2011, 74:1166-1173, reproduced by permission of John Wiley and Sons.

(G) Koch K, Bhushan B, Barthlott W: Multifunctional surface structures of plants: an inspiration for biomimetics. Progress in Materials Science 2009, 54:137-178, reprinted by permission of Elsevier.

\section{Author details}

'Department of Biology, Stanford University, Stanford, CA 94305-5020, USA. ${ }^{2}$ Department of Biotechnology/Department for Bio and Environmental Sciences, University of Helsinki, Helsinki FIN-00014, Finland. ${ }^{3}$ Howard Hughes Medical Institute, Stanford, USA.

\footnotetext{
* Correspondence: dbergmann@stanford.edu

'Department of Biology, Stanford University, Stanford, CA 94305-5020, USA

${ }^{3}$ Howard Hughes Medical Institute, Stanford, USA

Full list of author information is available at the end of the article
}

Received: 11 March 2013 Accepted: 12 March 2013

Published: 4 April 2013

\section{Reference}

1. Vatén, Bergmann: Mechanisms of stomatal development: an evolutionary view. EvoDevo 2012, 3:11.

doi:10.1186/2041-9139-4-11

Cite this article as: Vatén and Bergmann: Correction: Mechanisms of stomatal development: an evolutionary view. EvoDevo 2013 4:11.

\section{Submit your next manuscript to BioMed Central and take full advantage of:}

- Convenient online submission

- Thorough peer review

- No space constraints or color figure charges

- Immediate publication on acceptance

- Inclusion in PubMed, CAS, Scopus and Google Scholar

- Research which is freely available for redistribution

Submit your manuscript at www.biomedcentral.com/submit
() Biomed Central

\section{Biomed Central}

(c) 2013 Vatén and Bergmann; licensee BioMed Central Ltd. This is an Open Access article distributed under the terms of the Creative Commons Attribution License (http://creativecommons.org/licenses/by/2.0), which permits unrestricted use, distribution, and reproduction in any medium, provided the original work is properly cited. 